\title{
THE INTERNATIONAL FINANCE CORPORATION AND FOREST LOSS: A CROSS-NATIONAL ANALYSIS
}

\author{
John M. Shandra \\ Department of Sociology \\ State University of New York at Stony Brook \\ jshandra@notes.cc.sunysb.edu \\ Eric Shircliff \\ Department of Sociology \\ State University of New York at Stony Brook \\ eric.shircliff@sunysb.edu \\ Bruce London \\ Department of Sociology \\ Clark University \\ blondon@clarku.edu
}

\begin{abstract}
We conduct the first cross-national study to consider the impact of the World Bank's International Finance Corporation loans on forests. In doing so, we analyze data for a sample of sixty-one low and middle income nations for the period of 1990 to 2005. We find substantial support for dependency theory that low and middle income nations that receive an International Finance Corporation loan tend to have higher rates of deforestation than low and middle income nations that do not receive such a loan. We also find that other aspects of World Bank lending affect forest loss including structural adjustment and investment lending. We conclude with a discussion of the findings, theoretical implications, methodological implications, policy implications, and possible directions for future research.
\end{abstract}

\section{INTRODUCTION}

The "debt crisis" of the 1980s highlighted the inability of many low and middle income nations to generate enough revenue to make payments on their mounting foreign debts (Peet 2003). This was brought on by the sudden increase in the price of oil coupled with low and middle income nations borrowing large amounts of money from the World Bank in order to finance massive agriculture, forestry, mining, and infrastructure projects (Barbosa 2001). The World Bank responded to the debt crisis by rescheduling loan payments and providing new loans (McMichael 2004). These new loans, known as structural adjustment, are designed to resolve balance of payment issues by requiring indebted nations to institute a variety of economic policy reforms in order to receive the money (Peet 2003). The economic policy reforms include devaluing currency, reducing government spending, liberalizing trade, and privatizing government assets 
(Clapp and Dauvergne 2005). The underlying logic behind structural adjustment is an attempt to generate hard currency for debt repayment by boosting exports and cutting government spending (Glover 1995).

While this "earn more" and "spend less" model of structural adjustment may facilitate debt repayment, dependency theory predicts that structural adjustment increases forest loss (George 1992)--see below for a brief discussion of dependency theory. The World Bank investment loans, which in part contributed to the debt crisis, are also hypothesized to increase deforestation. The harmful impact of these loans may be due to several factors. First, the World Bank often requires nations to increase agricultural and natural resource exports, liberalizing trade in extractive industries, and cut government spending for conservation, to receive a structural adjustment loan (George 1992). Second, the World Bank tends to make investment loans for projects in agriculture, forestry, mining, and infrastructure (Rich 1994). Third, structural adjustment and investment loans exacerbate poverty, which forces people to clear forests in order to grow subsistence crops for survival (Rudel 1993). Accordingly, there has been a substantial amount of research published that finds support for these dependency theory hypotheses. For example, Barbosa (2001) and Rich (1994) describe how World Bank investment loans for projects in agriculture, forestry, and road building led to immense forest loss in Brazil, India, and Indonesia. Hurst (1990) describes how the World Bank investment and structural adjustment lending increased deforestation in Malaysia, Papua New Guinea, Thailand, and Vietnam.

The impact of the World Bank's investment and structural adjustment loans on the natural environment clearly has been the subject of extensive study. However, there has been very little attention devoted to other aspects of World Bank lending. In 1956, the World Bank's International Finance Corporation (IFC) was established in order to increase private sector investment in low and middle income countries (Peet 2003). The IFC does this by providing loans to companies undertaking projects in low and middle income nations (Karliner 1997). It also offers government leaders and officials technical training and advisory services to better promote private sector investment (Peet 2003). See below for a complete description of the amounts, sectoral allocation, and geographical distribution of the IFC's lending portfolio.

Despite the lengthy history, there has been no cross-national research that examines how the IFC affects forests. This is somewhat surprising for a couple of reasons. First, some anecdotal evidence has been published by journalists and non-governmental organizations that documents how IFC loans to companies in the agriculture, forestry, mining, and infrastructure sectors increase deforestation (e.g., Friedman 2009). Second, data are available on IFC loans to companies in these extractive sectors (e.g., Findley et al. 2010). We elaborate upon these ideas in detail below and seek to address this gap in the literature by conducting a cross-national study that assesses the impact of IFC lending on forest loss.

We now turn to a brief discussion of dependency theory, the cross-national research on forest loss that corresponds with this perspective, and how the IFC fits into this theoretical framework. We then discuss the structure of the IFC and highlight the limited qualitative evidence that has been published by journalists and non-governmental organizations, which helps to describe how IFC loans may be contributing to forest loss. We then briefly elaborate upon why we include other theoretically relevant variables drawn from previous cross-national research in our discussion of the independent variables. Accordingly, our approach involves respecifying cross-national models of deforestation to include a measure of IFC lending. We 
conclude with a discussion of the methodology, sample, findings, theoretical implications, methodological implications, policy suggestions, and possible directions for future research.

\section{DEPENDENCY THEORY AND THE INTERNATIONAL FINANCE CORPORATION}

According to dependency theory, economic relationships between high, middle, and low income nations are structurally detrimental for the middle and low income nations because of the inherent dynamics of international capitalism (Evans 1979; Amin 1976). The high income nations become wealthy by exploiting surplus labor and natural resources from low and middle income nations (Frank 1969). Consequently, low and middle income nations suffer a range of problems.

This exploitation tends to take three distinct forms. During the 1970s, dependency theorists explained how exports (e.g., export composition, commodity concentration, export partner concentration, etc.) affected low and middle income nations (Amin 1974). Accordingly, Shandra (2007a) finds that higher levels of forest exports, commodity concentration, and export partner concentration are associated with higher rates of forest loss-see also Austin (2010). In the 1980s, dependency theory became concerned with the detrimental impact of multinational corporations in low and middle income nations (Bornschier and Chase-Dunn 1985; Evans 1979). Recently, Jorgenson (2008) finds that higher levels of multinational corporate investment are associated with higher rates of deforestation. The debt crisis shifted the focus of dependency theorists to the effects of debt repayment and concomitant structural adjustment loans in low and middle nations during the 1980s (Magdoff 1986). For instance, Rudel and Roper (1997) find that higher levels of debt repayment correspond with higher rates of forest loss. Shandra, Shandra, and London (2008) find that higher levels of International Monetary Fund structural adjustment are associated with more deforestation.

We use dependency theory to inform our study of the IFC for a couple of reasons. First, the World Bank operates the IFC and other aspects of World Bank lending have been the subject of extensive study by scholars working in this theoretical tradition. Second, the IFC provides loans directly to multinational corporations, which have been shown to adversely affect forests in low and middle income nations. We now turn to a discussion of IFC operations and go on to elaborate upon why they may well increase forest loss.

\section{INTERNATIONAL FINANCE CORPORATION LENDING AND ADVISORY SERVICES}

The IFC offers several different financial products to accomplish its goal of facilitating private sector investment in low and middle income nations. The largest portion of its portfolio includes loans made directly to companies operating in low and middle income nations. The amounts of the loans tend to range between $\$ 1$ million to $\$ 100$ million, carry market interest rates, and have maturities of 5 to 7 years at origination (International Finance Corporation 2010). The IFC usually limits its financing for a new project to 25 percent of the total estimated cost. It will finance up to 50 percent of the projected costs to expand an existing project (International Finance Corporation 2010). The IFC does so to ensure participation by other private sector investors. These loans differ from World Bank project loans that fund large scale infrastructure projects and are made on a concessional basis (i.e., longer repayment schedule and below market 


\section{JOURNAL OF WORLD-SYSTEMS RESEARCH}

interest rates) (McMichael 2001). They differ from World Bank structural adjustment loans, which tend to be repaid over three to five year periods and require governments to implement macro-economic policy reforms in return for the money (Peet 2003).

Similarly, the IFC provides syndicated loans in order to increase private sector investment in low and middle income nations. A syndicated loan involves a group of lenders who work together to provide funds to a company (International Finance Corporation 2005). The International Finance Corporation puts up the largest share of a syndicated loan and performs duties that include dispersing cash and administrative tasks. The remaining portions of the loan come from commercial banks, hedge funds, pension funds, and mutual funds. A syndicated loan allows the IFC to raise a significantly larger amount of capital than that represented by its own exposure. The commercial banks, hedge funds, and mutual funds benefit because they are able to make investments in projects considered too risky without IFC support (International Finance Corporation 2008).

This is the case for a few reasons. First, the World Bank's Multilateral Guarantee Agency offers risk insurance at discounted rates to participants in IFC syndicated loans (Karliner 1997). Second, syndicated loan participants may also be exempt from holding currency reserves to cover losses that may occur from investing in certain countries (International Finance Corporation 2010). Third, the IFC enjoys "Preferred Creditor Status," which means that governments grant the IFC preferential access to foreign currency in the event that a country experiences a foreign exchange crisis (International Finance Corporation 2009). This status mitigates transfer and convertibility risk for the IFC and its partners involved in a syndicated loan.

The IFC has made $\$ 12,627,000,000$ worth of loans to companies for projects in low and middle income nations during 2010. These loans include loans made directly to businesses and syndicated loans (International Finance Corporation 2010). Of this total, approximately four percent, or $\$ 536,000,000$, funded projects in the agricultural and forestry sectors. Eight percent, or $\$ 1,053,000,000$, funded projects are in the mining sector. About twelve percent, or $\$ 1,578,000,000$, are funded infrastructure projects (International Finance Corporation 2010). The sectoral distribution of the IFC's total lending portfolio is slightly higher than their sectoral allocation levels for 2010. Six percent of the IFC's overall portfolio funds agriculture and forestry, nine percent funds mining, and sixteen percent funds infrastructure (International Finance Corporation 2010). See below for the types of projects for which the IFC tends to loan money to companies in each sector. The loans are also disbursed fairly evenly across geographical regions, with twenty-four percent of the loans financing projects in Latin America, twenty-three percent financing projects in Eastern Europe, twenty percent financing projects in Asia, nineteen percent financing projects in Sub-Saharan Africa, and twelve percent financing projects in the Middle East (International Finance Corporation 2010).

The IFC encourages government involvement in its lending in several ways. In the 1950s, the World Bank often required governments to create development parastatals or semiautonomous government agencies (e.g., development boards, electricity generating companies, water authorities, etc.), charged with the task of promoting economic growth in order to receive a World Bank loan (McMichael 2001). The World Bank and these newly created agencies engaged in a mutually rewarding pattern of interaction. The parastatals borrowed heavily from the World Bank in order to expand their mandate, which, in turn, created a continuous demand for World Bank loans (Bryant and Bailey 1997). This process continues to play out today. The IFC 
encourages these parastatals to invest in syndicated loans (International Finance Corporation 2007). Similarly, the IFC lends to companies that seek to enter into partnerships with governments in low and middle income nations. These partnerships tend to involve companies paying a government to lease property or other assets (e.g., forest, mine, pipeline, etc.) for a specified time period (International Finance Corporation 2010). While the leases provide governments with revenue, governments provide companies with financial incentives (e.g., tax holidays) and regulatory concessions (e.g., environmental law exemptions) to help the companies increase profits (International Finance Corporation 2010). It is important to highlight that Karliner (1997) notes many low and middle income nations have already put into place regulations that create a "good business climate" for corporations. This is because many nations are recipients of World Bank or International Monetary Fund structural adjustment loans, which require governments to institute a variety of economic policy reforms (e.g., tax breaks, environmental law exemptions, minimum wage elimination, and outlawing strikes, protests, and unions) in return for the money (Peet 2003). For instance, in 1990, forty percent of low and middle income nations that received an IFC loan were under World Bank structural adjustment loans (World Bank 2010).

Additionally, the IFC provides advisory services and technical training, which help to create additional demand for its loans (International Finance Corporation 2010). In this regard, the IFC establishes "trust funds" for low and middle income nations that offer training courses in the theory and practice of "development" for government officials. This training is predicated upon private sector involvement when building infrastructure and increasing exports of natural resource and agricultural goods (International Finance Corporation 2009). There is also a focus on how a government can create a "good business climate" by offering financial incentives and regulatory concessions to companies investing in a country. The IFC does this in a few ways. In one program, it collects, summarizes, and analyzes data on "best practice" investment reform efforts (International Finance Corporation 2005). The results are distributed to government officials in a manual to use when deciding which reforms to undertake. The IFC also offers more practical instruction, which includes techniques for successfully applying for IFC loans and preparing environmental impact assessments for loans (International Finance Corporation 2007). The IFC also works with governments to simplify the licensing, permitting, and inspecting of businesses in order to reduce cost of compliance for companies. This involves collecting data on business regulations and enforcement at the national and municipal levels. The IFC then prepares reports for government officials that highlight regulatory bottlenecks and how governments can eliminate them (International Finance Corporation 2010).

\section{INTERNATIONAL FINANCE CORPORATION OPERATIONS AND FOREST LOSS}

The IFC maintains that by facilitating private sector investment via its loans and advisory services it helps stimulate economic growth and alleviate poverty in low and middle income nations (International Finance Corporation 2010). However, its operations may adversely affect the natural environment. Some anecdotal evidence from newspaper accounts and experiences observed by members of non-governmental organizations suggest that IFC projects are increasing forest loss in low and middle income nations (Lilley 2004). This is because it provides loans to companies carrying out projects in extractive sectors that include agriculture, forestry, natural 


\section{JOURNAL OF WORLD-SYSTEMS RESEARCH}

gas, oil, and mining projects. Let us now turn to a discussion of the qualitative evidence to illustrate this point.

The IFC provided two $\$ 30$ million loans to Amaggi Exportai e Importai Limitada in order to increase exports of soy from Brazil (Lilley 2004). The majority of the soy exported is grown in the Amazon and is destined for the United States and Europe where it will be used as cattle feed (Austin 2010). The money was to help the company expand its processing, storage, and distribution facilities. It was also to be used to supply 900 medium sized farmers from whom the company buys the majority of soy it sells with low interest loans to acquire seeds, pesticides, and fertilizers (Lilley 2004).

While the IFC determined that the loans would have limited environmental impacts, Fearnside (2007) argues that the loans have increased forest loss in a few ways. First, soy farmers increased the amount of land under cultivation due to the access to the low interest loans for seeds, pesticides, and fertilizers. This involved the clearing of forests via slash-and-burn techniques. Second, soy farmers began cultivating savannah and transitional forests, which pushed cattle ranchers and subsistence farmers to clear areas deeper in the jungle. Third, the IFC's involvement led several commercial banks to lend Amaggi Exportai e Importai Limitada an additional \$230 million (Lilley 2004). These loans helped to fund the construction of BR-163 from Cuiaba to the deep-water port in Santarem in order to facilitate soy exports. According to the Amazonian Institute for Environmental Research, however, this 1,600-kilometer road resulted in the clearance of 10 million hectares of forest and opening up additional forests to colonization (Lilley 2004).

The IFC has also provided loans for companies in the forestry sector, which have resulted increased deforestation. For example, the IFC provided a $\$ 10$ million loan during the 1980 s to Congolese Industrielle des Bois, which is a subsidiary of Hinrich Feldmeyer based in Germany (World Rainforest Movement 2005). The money was to be used to increase exports of logs on a 480,000 hectare tract in the Pokola region of the Congo. The logging concession is located just outside of N'doki national park, a region the size of Belgium, which contains the largest intact ebony, sipo, and sapelli forests. According to World Rainforest Movement, Congolese Industrielle des Bois have been clear cutting portions of the park in search of these highly valued tree species, using chemicals to camouflage the trees to prevent identification by forestry officials, and transporting them across the border to Cameroon where the logs are exported to Asia (World Rainforest Movement 2005).

The IFC has not limited its forestry sector lending to only logging. The IFC began lending money to several companies in Indonesia to increase palm oil exports. The biggest loans were given to Wilmar International Limited, which received approximately $\$ 100$ million between 2003 and 2007 (Gilbert 2010). The loans were used to finance land acquisition for new plantations, construction of processing facilities, and building of infrastructure to facilitate refined palm oil exports (Forest Peoples Program 2007). The money was also used to buy additional palm fruits from small-scale farmers.

Nevertheless, the World Bank's Office of the Compliance Advisor Ombudsman has found that the IFC helped to finance forest loss in Indonesia. This occurred for several reasons. First, much of money was used to build infrastructure, especially roads. However, the roads led to large areas of forest being cleared during the construction process (Friedman 2009). They also precipitated migration to previously inaccessible areas where settlers cleared forests to grow subsistence crops. However, it was the IFC's classification of its loans as "Category C" (i.e., a 
listing signifying that a project has little or no adverse environmental impact) that led to substantial forest loss. This is because Wilmar International Limited and its subsidiaries did not have to carry out an environmental impact assessment. As a result, the company engaged in practices that minimized production costs but accelerated forest loss (Friedman 2009). These practices included using slash and burn techniques to clear forests, clearing natural forests, clearing trees in protected areas, clearing peat forests, and appropriating indigenous people's land without compensation or due process (Friedman 2009).

The IFC has funded projects in the natural gas and oil sectors, which may also increase forest loss. For example, Basic Petroleum International received two IFC loans in 1994 totaling $\$ 44$ million for its operations in Guatemala (Bowles et al. 1999). The loans were to increase production from the oil field 8,500 to 20,000 barrels daily by building a 234 kilometer pipeline and maintenance road to transport the oil from Xan to the company's refinery in La Libertad. The pipeline was intended to save Basic Petroleum International about $\$ 5$ million annually by decreasing transport costs associated with tanker trucks from $\$ 4$ per barrel to $\$ 1.63$ per barrel. However, Bowles et al. (1999) estimate that project will contribute to extensive forest loss in the region. The pipeline follows an existing road for approximately 20 kilometers but then splits apart from the road and enters Laguna del Tigre National Park. The building of the pipeline has led to the clearing of previously undisturbed forests in the park (Bowles et al. 1999). When the pipeline exits Laguna del Tigre National Park, 80 kilometers of road were built to connect the pipeline with the refinery. The project contributed directly to forest loss when trees were cut down to make way for the pipeline. However, Bowles et al. (1999) estimates that between 400 and 2,400 hectares of forest will be cleared for every kilometer of road built. This will be the result of an influx of colonists and the expansion of slash and burn agriculture along the road from Laguna del Tigre National Park to La Libertad to support the migrants.

The qualitative evidence clearly indicates that IFC lending should be associated with increased forest loss. This is because the IFC supports projects in sectors that lead to deforestation (e.g., agriculture, logging, oil exploration, and mining). At the same time, IFC projects often lead to roads being built into previously forested areas, allowing for an influx of migrants that clear forests. Despite these claims, there has been no cross-national research that empirically evaluates this relationship. We seek to address this large gap in the literature here. In the process, we must also take into account other factors that have been shown to influence deforestation in previous research. We draw upon earlier cross-national studies on the topic to inform our model specifications. We turn to a discussion of these factors after talking about the dependent variable.

\section{DEPENDENT VARIABLE}

The dependent variable for our analysis is the average annual percentage change in natural forest area from 1990 to $2005 .{ }^{1}$ Please note that deforestation is signified by a positive value for

1 Jorgenson, Austin, and Dick (2009) use a panel regression design (i.e., ordinary least squares regression with fixed effects) to analyze cross-national data on forest loss from 1970 to 2000 . The authors find that primary sector exports from poorer to wealthier nations tend to increase forest loss. We choose not to use 
interpretation purposes. The data may be obtained from the Food and Agriculture Organization (2005). This measure includes land greater than half a hectare in size with trees higher than five meters and a canopy cover of more than ten percent. A natural forest consists only of native forest species with the possible exception of small areas of natural regeneration or assisted natural regeneration. This measure excludes forest plantations, which are areas established through planting or seeding (Food and Agricultural Organization 2005). Most cross-national research (e.g., Shandra 2007a; Jorgenson 2006) examines the average annual percentage change in total forest area, which includes natural forest areas as well as forest plantations. A forest plantation often involves relative homogeneity in the types of species grown for commercial purposes (Food and Agriculture Organizations 2005). We use natural forest area data because we are interested in the effect of World Bank lending on land that is not already being intensively managed for commercial production (e.g., forest plantations). We provide descriptive statistics and a bivariate correlation matrix in Table 1. All data come from the World Bank (2003) unless otherwise noted. (Table 1 goes about here.)

\section{WORLD BANK INDEPENDENT VARIABLES}

\section{International Finance Corporation Loan}

The main independent variable is whether a low and middle income nation has a project financed by the IFC in 1990. This is a dummy variable where we code nations that have an IFC loan in the agriculture, forestry, and mining sectors with a value of one. We obtain the data from AidData (Findley et a. 2010). All other low and middle income nations serve as the reference category and are coded with a value of zero. We hypothesize that low and middle income nations that have a project financed by the IFC should have higher rates of deforestation than low and middle income nations that do not have an IFC loan in place.

\section{Structural Adjustment Loan}

The second independent variable is whether a low and middle income nation has been under World Bank structural adjustment for at least one year by 1990. This is a dummy variable where we code nations that were undergoing adjustment in the areas of agriculture, forestry, or mining with a value of one. The World Bank's Projects and Operations Database identifies the major sectors of all its loans (e.g., forestry, agriculture, and mining) (World Bank 2010). All other nations serve as the reference category and are coded with a value of zero. According to dependency theory, we hypothesize that low and middle income nations undergoing World Bank structural adjustment in the primary sector should have higher rates of deforestation than low and middle income nations not undergoing World Bank adjustment in this sector. As noted above, this is because the policy reforms that must be adopted to receive a structural adjustment loan include increasing exports of natural resources, reducing government spending for environmental protection, and liberalizing trade in extractive industries, which all have been linked to increased

such an approach because the IFC did not make a large percentage of loans in the agriculture, forestry, and mining sectors prior to the 1990. 
deforestation (Rich 1994). Shandra, Shircliff, and London (2010) find support for this line of reasoning.

\section{Investment Loan}

The third independent variable is whether a low and middle income nation had implemented a World Bank investment loan for at least one year by 1990. This is a dummy variable where low and middle income nations that have implemented an investment loan in the agriculture, forestry, and mining sectors are coded with a value of one. All other low and middle income nations serve as the reference category and are coded with a value of zero. These data may be obtained online from the World Bank's Projects and Operations Database (World Bank 2010). According to dependency theory, low and middle income nations that implement a World Bank investment loan in these sectors should have higher rates of deforestation than low and middle income nations that have not implemented one of these loans. This is because World Bank investment loans often fund large scale agricultural or infrastructure projects that lead to forest loss (Bryant and Bailey 1997).

We use dummy variables to operationalize our World Bank variables rather than an interval-ratio measure for a few reasons. First, there is incomplete data on amount of World Bank loans disbursed. The World Bank reports data on the amount it initially agrees to lend to a low and middle income nation. In some instances, however, a nation does not receive all of the money allocated (Abouharb and Cingranelli 2009). In other instances, a nation receives more money than originally allocated. Second, the World Bank often disburses money over several years. However, data on the amount dispersed in any one year as part of a loan are not available. Third, Tockman (2001) conducts an analysis of World Bank and International Monetary Fund structural adjustment loan documents and finds that macro-economic policy reforms attached to these loans are similar across low and middle income nations despite the size of the loan. Fourth, the use of a dummy variable allows us to estimate two stage treatment effects models to ensure that selection bias is not a problem in the analysis. This is imperative to ensure that the relationship between World Bank lending and forest loss is not due to selection bias. We describe this procedure in endnote two.

\section{OTHER RELEVANT INDEPENDENT VARIABLES}

\section{Debt Service Ratio}

In addition to the pressure to adjust their economies while under a structural adjustment loan, low and middle income nations must continually service their foreign debts. Therefore, we include the sum of principal and interest payments to multilateral lenders in foreign currency, goods, or services on long-term public and publicly guaranteed private debt with maturity of one year or longer as a percentage of goods and services exports in 1990. We hypothesize that higher levels of debt service should be associated with higher rates of deforestation because indebted nations increase exports of logs, minerals, and agricultural goods in order to generate revenue to make interest and principal payments (Marquart-Pyatt 2004). Shandra, Shandra, and London (2008) and Marquart-Pyatt (2004) find support for this hypothesis. 


\section{Non-Governmental Organizations}

We also consider how non-governmental organizations impact forest loss by including the number of international non-governmental organizations working on "environmental" and "animal rights" issues in a nation per capita for 1990. The data were collected by Smith and Wiest (2005) from the Yearbook of International Associations. It is important to note that the data exclude labor unions, institutes, and foundations (Smith and Wiest 2005). Shandra (2007a) and Schofer and Hironaka (2005) find that higher levels of non-governmental organizations are associated with lower rates of deforestation. This may be the case because non-governmental organizations finance local conservation projects, support social movement activity around environmental issues, shape the language of environmental agreements, and write codes of conduct for business (Schofer and Hironaka 2005).

\section{Environmental Ministry}

We also include a dummy variable that measures whether or not a nation had an environmental ministry. We code nations that had an environmental ministry in 1990 with a value of one. All other nations are coded with a value of zero. The data may be obtained from Frank (1999). We hypothesize that nations with an environmental ministry should have lower rates of deforestation than nations without an environmental ministry. This is because environmental ministries tend to implement programs that may reduce deforestation (e.g., demarcating protected areas or monitoring of forests for illegal logging) (Frank, Hironaka, and Schofer 2000).

\section{Democracy}

We use the average of Freedom House's (1997) political rights and civil liberties scales to measure democracy. Political rights reflect the degree to which a nation is governed by democratically elected representatives and has fair, open, and inclusive elections. Civil liberties reflect whether within a nation there is freedom of press, freedom of assembly, general personal freedom, freedom of private organizations, and freedom of private property. Both variables have a seven-point scale with the following codes: free (1-2), partially free (3-5), and not free (6-7). We multiply our index by negative one so that high scores correspond with high levels of democracy. We hypothesize that higher levels of democracy should correspond with lower rates of deforestation. This is because democratic nations tend to have higher levels of activism than repressive nations because they provide their citizens ways to engage in public dialogue (Paxton 2002). This often occurs by granting the freedoms of speech, press, and assembly (Midlarsky 1998). Further, democratic nations must be more responsive to political activism because of electoral accountability (Ehrhardt-Martinez, Crenshaw, and Jenkins 2002). The responsiveness of leaders in a democracy is partially based upon the need for public officials to win popular elections to maintain their positions. The officials, who fail to address the needs of citizens or give the impression of concern, face the risk of losing a subsequent election. In this regard, Li and Reuveny (2006) find support for this hypothesis. 


\section{Gross Domestic Product}

As is standard in such analyses, it is incumbent on us to take into account the size of a nation's economy in order to make sure that any effects discovered are independent of a nation's level of wealth. In this regard, we employ a measure of gross domestic product per capita in constant 2000 United States dollars. We log this variable to correct for its skewed distribution. Burns, Kick, and Davis (2003) find that higher levels of economic development are associated with lower rates of deforestation. They attribute this finding to wealthier nations "externalizing" their environmental costs by importing natural resources from poorer nations-see also Jorgenson (2006).

\section{Economic Growth}

We also include the average annual economic growth rate from 1980 to 1990 . It is thought that economic growth should be associated with higher rates of deforestation. This is because there are large amounts of capital available for investment in activities that accelerate forest loss during periods of economic expansion (Rudel 1989). Jorgenson (2006) and Rudel (1989) find support for this hypothesis.

\section{Agricultural and Forestry Based Economic Activity}

It is also important to include a measure of domestic economy structure (Ehrhardt-Martinez, Crenshaw, and Jenkins 2002). Therefore, we include value added from agriculture and forestry as a percentage of gross domestic products for 1990. We expect this measure should be associated with higher rates of deforestation because these types of economic activities (e.g., forestry, agriculture, and mining) are presumed to put greater pressure on forests than services or manufacturing. Shandra, Shandra, and London (2008) find that higher levels of agricultural and forestry based economic activity are associated with higher rates of forest loss.

\section{Total Population Growth}

We also include the average annual percentage change in total population growth from 1980 to 1990 in the analysis. It is thought that population growth should be associated with increased forest loss because the "geometric" growth in population outstrips "arithmetic" growth in the means of subsistence, leading to "carrying capacity" problems including deforestation (Rudel 1989). Ehrhardt-Martinez (1998) and Rudel (1989) find that higher rates of total population growth are associated with higher rates of forest loss.

\section{Rural and Urban Population Growth}

York, Rosa, and Dietz (2003) argue that it is important to "decompose" demographic factors in cross-national research. That is, scholars should examine not only overall growth rates per se but also population growth in different contexts. Jorgenson and Burns (2007) find that higher rates of rural population growth are associated with increased deforestation while higher rates of urban population growth are associated with lower rates of deforestation. They argue that expanding 
urban centers often create economic opportunities other than agricultural ones, which attract people to cities and relieve pressure on forest. Ehrhardt-Martinez, Crenshaw, and Jenkins (2002) find that higher rates of rural population growth are associated with higher rates of deforestation. Thus, we examine the differential effects of rural and urban population growth here. To do so, we include the average annual percentage changes in rural and urban populations from 1980 to 1990 in the models. The data are based upon changes in the percentage rural and urban rather than change in total numbers of people living in rural or urban areas. ${ }^{2}$

\section{Tropical Land Area}

We also include the amount of land area within a nation that is classified as tropical (York, Rosa, and Dietz 2003). The World Resources Institute (2005) classifies land area as "tropical" if it has a mean monthly temperature that exceeds eighteen degrees Celsius. We hypothesize that low and middle income nations with more tropical land area should have higher rates of deforestation because these nations tend to have more valuable tree species that are in demand on the world market (Rudel 1989). Shandra, Shircliff, and London (2010) and Shandra, Leckband, and London (2009) find support for this line of reasoning

\section{Data Quality}

We also take into account the data quality of the deforestation estimates. The data may be obtained from the Food and Agriculture Organization (2005). We classify forestry statistics as being highly reliable if they are based upon remote sensing surveys or current national field sampling estimates (Shandra 2007b). We classify forestry statistics as having low reliability if they are based upon expert estimates, which often involves extrapolation from an outdated national inventory. As such, we include a dummy variable to measure the reliability of the deforestation data, identifying those nations in which forest cover measures are based upon remote sensing surveys or current national field sampling estimates and should, therefore, be of higher quality $(1=$ high data quality). The reference category includes nations whose forestry estimates are based upon expert estimates or an outdated inventory. Shandra (2007b) and Jorgenson (2006) find that it is important to include a measure of data quality in cross-national analyses of forest loss.

2 Ehrhardt-Martinez, Crenshaw, and Jenkins (2002) employ a novel measure of rural-to-urban migration in their cross-national study of forest loss by subtracting the rural population growth from the urban population growth rate. They argue that because fertility tends to be high in rural areas then a positive value for urban population growth above the rate for rural areas should attributed to rural-to-urban migration. Initially, Ehrhardt-Martinez, Crenshaw, and Jenkins (2002) find no support that this measure is associated with forest loss. However, they include an interaction term between rural-to-urban migration and rural population growth. The coefficients for the interaction term are statistically significant, indicating that rural-to-urban migration mitigates the harmful effects of rural population growth. We test this hypothesis in our analysis but do not find support for it. This may be because of the different time period under examination. 


\section{Natural Forest Stocks}

It is necessary to include a measure that controls for the potentially biasing effects of relative abundance or scarcity of forest resources (Rudel 1989). Therefore, we include natural forest area in a nation for 1990. We log this variable to control for its skewed distribution. The data may be obtained from the Food and Agricultural Organization (2005). Austin (2010), Jorgenson (2006), Ehrhardt-Martinez (1998), and Rudel (1989), include a forest stock variable in their analyses.

\section{METHODOLOGY}

We use ordinary least squares regression to examine the impact of the IFC's loans on forest loss. In doing so, it is imperative to check for potential violations of regression assumptions. First, we calculate and present the mean and highest variance inflation factor scores for each of the models in order to determine if multicollinearity is a problem in the analysis. The highest and mean variance inflation factor scores do not exceed a value of five for any model, indicating multicollinearity should not be a problem (York, Rosa, and Dietz 2003). Second, we follow the standard practice regarding the identification influential cases and outliers from the analysis. There do not appear to be any potential problems with influential cases based upon Cooks $\mathrm{d}$ or outliers based upon standardized residuals.

\section{SAMPLE}

We include all nations that are classified as "low" and "middle" income according to the World Bank's (2003) income classification system. ${ }^{3}$ We do not include nations formed following the collapse of the Soviet Union because there are no data for them in 1990. This yields a sample of sixty-one nations for which complete data are available. We exclude high income nations from the sample because they are not recipients of IFC loans. ${ }^{4}$

\footnotetext{
3 The following sixty-one nations are included in the analysis. They include Albania, Algeria, Angola, Argentina, Bangladesh, Benin, Bolivia, Brazil, Burkina Faso, Central African Republic, Chad, Chile, China, Colombia, Congo, Costa Rica, Cote D'Ivoire, Ecuador, El Salvador, Ethiopia, Gabon Gambia, Ghana, Guatemala, Guinea, Guinea Bissau, Honduras, Hungary, India, Indonesia, Jamaica, Kenya, Lesotho, Madagascar, Malawi, Malaysia, Mauritius, Mexico, Mozambique, Nepal, Nigeria, Panama, Papua New Guinea, Paraguay, Peru, Philippines, Romania, Rwanda, Senegal, Sierra Leone, Sri Lanka, Swaziland, Tanzania, Thailand, Togo, Trinidad, Turkey, Uruguay, Zambia, and Zimbabwe.

4 It is not possible to conduct separate analyses for low and middle income nations for a couple of reasons. First, there are not enough cases in either sample if we divide the sample into two groups. Second, Peet (2003) finds that the macro-economic policy reforms attached to World Bank structural adjustment loans are the same for low and middle income and middle income nations. All of the loans included indebted nations to (1) increase exports, (2) cut government spending, and (3) liberalize trade among others. We have no reason to suspect that IFC loans are different for low and middle income nations.
} 
Table 1. Descriptive Statistics and Bivariate Correlation Matrix for Deforestation Analysis $(\mathbf{N}=\mathbf{6 1})$

(1) Deforestation, 1990-2005

(2) International Finance Corporation Loan, 1990

(3) Structural Adjustment Loan, 1990

(4) Investment Loan, 1990

(5) Debt Service, 1990

(6) Non-Governmental Organizations, 1990

(7) Democracy, 1990

(8) Environmental Ministry, 1990

(9) Gross Domestic Product, 1990

(10) Economic Growth Rate, 1980-1990

(11) Agricultural and Forestry Economic Activity, 1990

(12) Total Population Growth Rate, 1980-1990

(13) Rural Population Growth, 1980-1990

(14) Urban Population Growth Rate, 1980-1990

(15) Tropical Land Area, 1990

(16) Data Quality, 1990

(17) Natural Forest Stocks, 1990

$\begin{array}{cccc}\text { Mean } & \text { SD } & \text { Min. } & \text { Max. } \\ & & & \\ .064 & 1.020 & -1.652 & 4.442 \\ .245 & .434 & 0 & 1 \\ .295 & .459 & 0 & 1 \\ .639 & .484 & 0 & 1 \\ 19.432 & 12.262 & 0 & 64.73 \\ 1.012 & 1.369 & 0 & 6.604 \\ -4.187 & 1.653 & -7 & -1 \\ . .377 & .488 & 0 & 1 \\ 7.618 & .796 & 6.041 & 9.113 \\ 2.239 & 4.373 & -10 & 11 \\ 24.42 & 12.800 & 3 & 61 \\ 1.120 & .312 & 0 & 4 \\ 1.054 & 1.460 & -2.654 & 3.923 \\ 3.781 & 1.633 & 0.3 & 7.141 \\ 79.060 & 38.077 & 0.693 & 13.154 \\ .404 & .492 & 0 & 1 \\ 8.645 & 2.187 & 0 & 100\end{array}$

(1)

(2) .156

(3) $\quad .167 \quad-.035$

(4) $\quad .233 \quad-.191 \quad .186$

$\begin{array}{lllll}(5) & -.020 & .114 & .235 & .398\end{array}$

$\begin{array}{llllll}\text { (6) } & -.209 & -.124 & .047 & -.130 & -.159\end{array}$

$\begin{array}{lllllll}(7) & -.094 & .007 & .074 & -.117 & .269 & .389\end{array}$

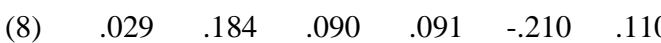

$\begin{array}{lllllll}\text { (9) } & -.307 & .065 & -.079 & -.266 & .012 & .203\end{array}$

$\begin{array}{lllllllll}(19) & -.307 & .065 & -.079 & -.266 & .012 & .203 & .047 & .097\end{array}$

$\begin{array}{llllllllll}(10) & .118 & .178 & .202 & .047 & .179 & .214 & .126 & -.122 & -.050\end{array}$

$\begin{array}{llllllllllll}(11) & .288 & -.145 & -.015 & .170 & -.016 & .141 & -.565 & -.108 & -.775 & -.096\end{array}$

$\begin{array}{llllllllllll}(12) & .238 & -.048 & -.194 & -.065 & -.004 & .039 & -.236 & -.170 & -.409 & .246\end{array}$

$\begin{array}{llllllllllll}(13) & .235 & -.185 & .016 & .007 & -.044 & .160 & -.350 & -.067 & -.587 & .130\end{array}$

$\begin{array}{llllllllllll}(14) & .200 & -.088 & -.108 & .164 & .181 & -.072 & -.357 & .001 & -.582 & .307\end{array}$

$\begin{array}{llllllllllll}(15) & .402 & -.025 & .002 & .073 & -.049 & .128 & -.080 & -.050 & -.342 & .227\end{array}$

$\begin{array}{llllllllllll}\text { (16) } & .156 & -.070 & .067 & .115 & -.096 & -.129 & -.306 & .135 & -.152 & -.226\end{array}$

(17) $\quad-.070$

$.147-.063$

$\begin{array}{lllllll}.117 & .134 & -.537 & -.084 & -.014 & -.069 & -.104\end{array}$

.386

$.518 \quad .552$

$.381 \quad .688 \quad .437$

$\begin{array}{llll}.109 & .464 & .249 & .210\end{array}$

$\begin{array}{lllll}.073 & .134 & .110 & .110 & -.036\end{array}$

$\begin{array}{lllll}.026 & .153 & -.046 & .080 & -.075\end{array}$ 
Table 2. Estimates of Deforestation, 1990-2005

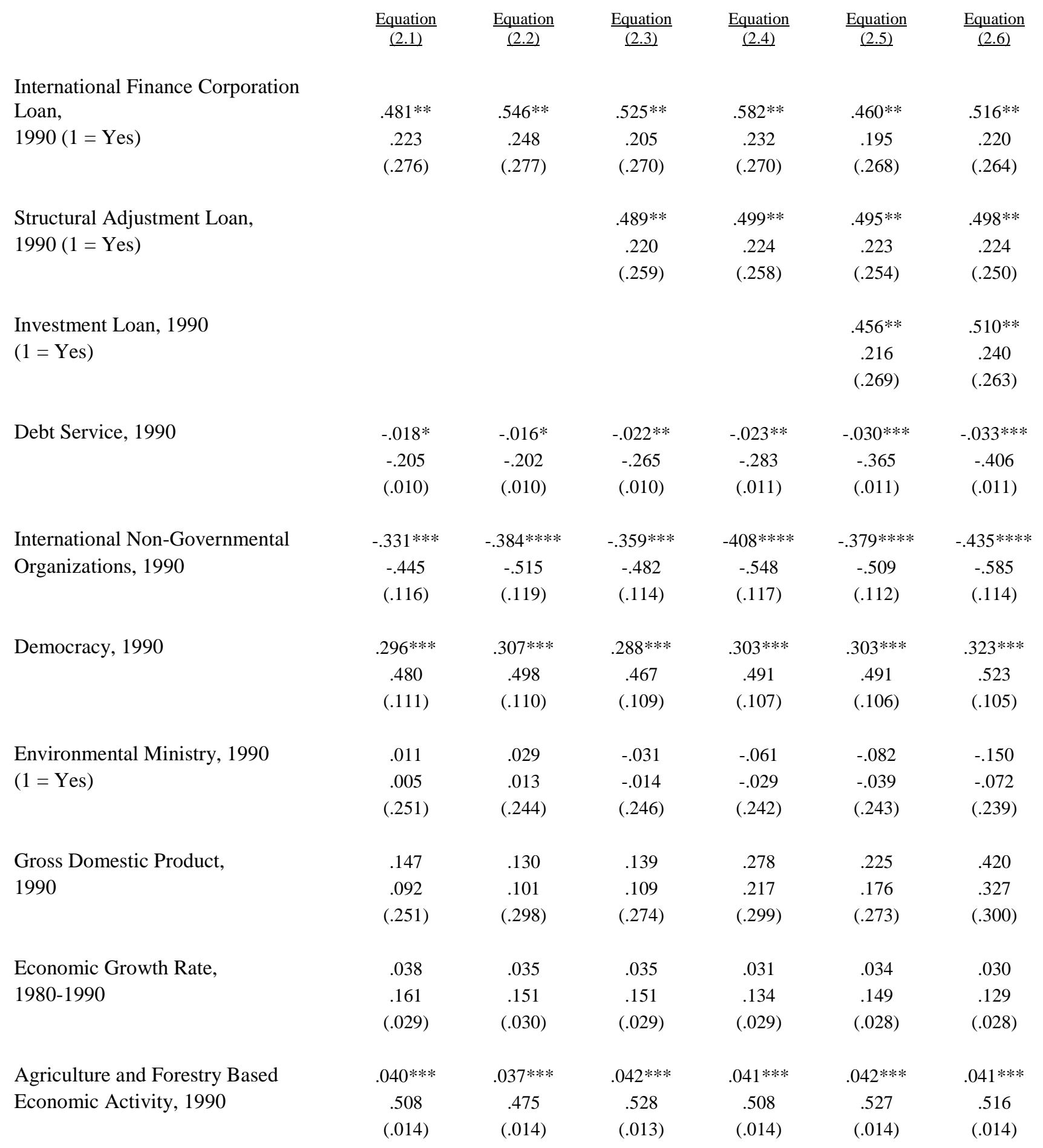




\section{Table 2 Continued From Previous Page}

\begin{tabular}{|c|c|c|c|c|c|c|}
\hline & $\frac{\text { Equation }}{\underline{(2.1)}}$ & $\frac{\text { Equation }}{\underline{(2.2)}}$ & $\frac{\text { Equation }}{\underline{(2.3)}}$ & $\frac{\text { Equation }}{\underline{(2.4)}}$ & $\frac{\text { Equation }}{\underline{(2.5)}}$ & $\frac{\text { Equation }}{\underline{(2.6)}}$ \\
\hline $\begin{array}{l}\text { Total Population Growth, } \\
1980-1990\end{array}$ & $\begin{array}{l}-.023 \\
-.007 \\
(.465)\end{array}$ & & $\begin{array}{c}.227 \\
.069 \\
(.472)\end{array}$ & & $\begin{array}{c}.425 \\
.130 \\
(.478)\end{array}$ & \\
\hline $\begin{array}{l}\text { Rural Population Growth } \\
\text { Rate, 1980-1990 }\end{array}$ & & $\begin{array}{c}.144^{*} \\
.206 \\
(.103)\end{array}$ & & $\begin{array}{l}.150^{*} \\
.214 \\
(.100)\end{array}$ & & $\begin{array}{c}.185^{* *} \\
.262 \\
(.099)\end{array}$ \\
\hline $\begin{array}{l}\text { Urban Population Growth } \\
\text { Rate, 1980-1990 }\end{array}$ & & $\begin{array}{l}-.030 \\
-.048 \\
(.093)\end{array}$ & & $\begin{array}{c}.024 \\
.039 \\
(.095)\end{array}$ & & $\begin{array}{c}.050 \\
.080 \\
(.093)\end{array}$ \\
\hline $\begin{array}{l}\text { Tropical Land Area, } \\
1990\end{array}$ & $\begin{array}{c}.011 * * * \\
.418 \\
(.003)\end{array}$ & $\begin{array}{c}.011 * * * * \\
.415 \\
(.003)\end{array}$ & $\begin{array}{l}.011^{* * *} \\
.406 \\
(.003)\end{array}$ & $\begin{array}{c}.011 * * * * \\
.426 \\
(.003)\end{array}$ & $\begin{array}{c}.010^{* * *} \\
.383 \\
(.003)\end{array}$ & $\begin{array}{c}.011^{* * * * *} \\
.422 \\
(.003)\end{array}$ \\
\hline $\begin{array}{l}\text { High Data Quality, } 1990 \\
\text { (1= Yes) }\end{array}$ & $\begin{array}{c}-.547 * * \\
-.264 \\
(.251)\end{array}$ & $\begin{array}{l}-.527 * * \\
-.254 \\
(.245)\end{array}$ & $\begin{array}{l}-.490 * * \\
-.236 \\
(.247)\end{array}$ & $\begin{array}{c}-.483 * * \\
-.233 \\
(.239)\end{array}$ & $\begin{array}{l}-.431 * * \\
-.208 \\
(.245)\end{array}$ & $\begin{array}{c}-.431 * * \\
-.208 \\
(.234)\end{array}$ \\
\hline Natural Forest Stocks, 1990 & $\begin{array}{l}-.044 \\
-.095 \\
(.064)\end{array}$ & $\begin{array}{l}-.055 \\
-.119 \\
(.061)\end{array}$ & $\begin{array}{l}-.055 \\
-.118 \\
(.062)\end{array}$ & $\begin{array}{c}-.059 \\
-0.127 \\
(.059)\end{array}$ & $\begin{array}{l}-.067 \\
-.144 \\
(.062)\end{array}$ & $\begin{array}{l}-.068 \\
-.140 \\
(.058)\end{array}$ \\
\hline Constant & $\begin{array}{c}.931 \\
(2.832)\end{array}$ & $\begin{array}{c}.372 \\
(2.953)\end{array}$ & $\begin{array}{l}-1.150 \\
(2.808)\end{array}$ & $\begin{array}{l}-1.027 \\
(2.961)\end{array}$ & $\begin{array}{c}-.929 \\
(2.792)\end{array}$ & $\begin{array}{l}-2.167 \\
(2.935)\end{array}$ \\
\hline R-Square & .439 & .461 & .478 & .502 & .509 & .541 \\
\hline Adjusted R-Square & .299 & .312 & .334 & .351 & .359 & .387 \\
\hline Number of Cases & 61 & 61 & 61 & 61 & 61 & 61 \\
\hline Highest VIF & 4.000 & 4.732 & 4.138 & 5.064 & 4.287 & 5.380 \\
\hline Mean VIF & 1.933 & 2.014 & 1.943 & 2.020 & 1.957 & 2.055 \\
\hline
\end{tabular}




\section{FINDINGS}

In Table 2, we present ordinary least square estimates of deforestation. ${ }^{5}$ In every equation, we include debt service, non-governmental organizations, democracy, environmental ministry presence, gross domestic product per capita, economic growth, agriculture and forestry based economic activity, tropical land area, data quality, and natural forest stocks. In equations (2.1) and (2.2), we examine only the impact of IFC lending. In equations (2.3) and (2.4), we add World Bank structural adjustment to the models. In equations (2.5) and (2.6), we add World Bank investment lending to the models. We consider the impact of total population growth in

5 According to Abouharb and Cingranelli (2009), selection bias may be a problem when examining the impact of World Bank lending in cross-national research. To determine if it is a problem in this analysis, we estimate two stage treatment effects models (Maddala 1986). In the first stage of the analysis, a selection equation is estimated using a probit model. The dependent variable in the selection equation is a dichotomous variable that indicates whether a nation has received an IFC loan. The independent variables are the factors hypothesized to influence whether or not a nation has received an IFC loan. We draw upon Abouhard and Cingranelli (2009) to specify independent variables included in the the first stage probit model. The independent variables are gross domestic product per capita, debt service, economic growth, foreign currency reserves, exchange rate value, international trade, alliance with the United States, and respect for worker rights. See Abouhard and Cingranelli (2009) for a discussion of these variables. The residuals of the probit analysis are saved and then used to construct a selection bias control factor commonly referred to as lambda. The lambda variable captures the effects of characteristics related to whether or not a nation receives a loan for independent variables not included in the model. In the second stage, a substantive equation is estimated using ordinary least squares regression. The dependent variable in the substantive equation of this analysis is deforestation. In this stage, lambda is included as an independent variable along with the dummy variable representing if a nation has received a loan. Because the coefficient for lambda reflects the effect of the variance unexplained by the predictors in the first stage of the model, we are controlling for the effects of the variables that predict whether a nation has been a recipient of an IFC loan. When selection bias is negligible, lambda is not statistically significant, and the least squares estimates of the substantive parameters have optimal properties. A statistically significant coefficient for lambda indicates that non-negligible sample selection bias exists in the model. The specifications for the deforestation model are the same as Table 2. The coefficients for the lambda coefficients are not statistically significant, indicating that selection bias should not be a problem in this analysis and the ordinary least squares estimates have optimal properties. The two-stage model we employ has been criticized by some because the first and second stage equations often have the same independent variables (Puhani 2000). According to Maddala (1986), if a linear probablity model is used in stage one for determining the inverse Mill's ration, potential problems with multicollinearity may emerge between lambda and other independent variables included in the second stage. This methodological issue has been addressed by Greene (2000), Maddala (1986), and Olsen (1980), who find that two stage treatment effects that use a probit model in stage one and a linear model in stage two do not suffer from identification problems even when a similar set of independent variables are used in both stages. Rivera, de Leon, and Koerber (2006) write, "This is because the probit models involves a non-linear function of its independent variables and, thus, the Mill's ratio calculated from it is a non-linear function of the exogenous variables in the model" (205). We confirm this assertion by calculating variance inflation factors scores for models including both lambda and find that they are in an acceptable range (e.g., less than five). This is most likely the case because we do include several identifying variables in the probit model that are correlated with receiving an IFC loan but not with forest loss in stage two (i.e., foreign currency reserves, alliance with the United Sates, etc.). 
odd numbered equations. We decompose this measure into rural and urban population growth rates in the even numbered equations.

We organize our analysis in this way for a few reasons. First, we want to establish that IFC loans impact forest loss and ensure that the effect is not "explained away" by World Bank structural adjustment and investment lending. Second, we want to avoid potential problems with excessive multicollinearity, which occurs when we include the various population growth measures in the same equations. Third, the sequential use of "cognate" but "distinct" indicators of more than one independent variable should shed considerable light on the complexity of dynamics involving the issue under investigation (Shandra, Shandra, and London 2008). If the population growth variables maintain similar effects on forest loss, for instance, then confidence in the findings regarding their harmful impact on the environment is enhanced. If they maintain different effects, then we demonstrate the utility of decomposing demographic factors in crossnational research. Fourth, multiple indicators help guard against potential problems associated with measurement error because one indicator may be imperfect but several measures are less likely to have the same error (Paxton 2002).

(Table 2 goes about here.)

Let us begin by discussing the findings pertaining to IFC lending and the other World Bank variables. We find substantial support that lending from the IFC adversely affects the natural environment. In equations (2.1) and (2.2), we find that the coefficients for this variable are positive and significant. In equations (2.3) and (2.4), the coefficients for International Finance Corporate lending remain positive and significant despite including World Bank structural adjustment lending. However, we also observe that World Bank structural adjustment is associated with increased forest loss in low and middle income nations. The coefficients for this variable are positive and significant in equations (2.3) and (2.4). In equations (2.5) and (2.6), the IFC variable coefficients are again positive and significant when we add World Bank investment lending to the models. In equations (2.5) and (2.6), we also find that World Bank investment lending is also associated with higher rates of deforestation. The coefficients for this variable are positive and significant in these two equations. Taken together, the findings clearly indicate that low and middle income nations that receive an IFC loan tend to have higher rates of forest loss than low and middle income nations that do not receive such a loan. Similarly, we find other aspects of World Bank lending, notably structural adjustment and investment loans, are associated with higher rates of deforestation.

A number of other factors also help to explain forest loss. First, we find support for the idea pertaining to the beneficial impacts of non-governmental organizations on the natural environment. The coefficients for this variable are negative and significant in every equation of Table 2. Second, we find that higher levels of debt service are associated with lower rates of deforestation. The coefficients for this variable are negative and significant in every equation of Table 2. Third, we find that higher levels of democracy are correlated with higher rates of deforestation. The coefficients for this variable are positive and significant in every equation of Table 2. Fourth, we also find that it is important to take into account the domestic economy structure of a nation. The coefficients for the agriculture and forestry based economic activity are positive and significant in all equations. ${ }^{6}$ Fifth, we find that it is important to decompose

6 We consider how other aspects of a country's domestic economy structure impact forest loss. It is thought that low and middle income nations with larger service and manufacturing economies may have 
population growth in cross-national research. We find that higher rates of rural population growth are associated with higher deforestation rates. The coefficients for this variable are positive and significant in the even numbered equations. Sixth, we find that it is important to include a couple of biophysical control variables. The coefficients for the tropical land area variable are positive and significant in every equation. The coefficients for the data quality variable are negative and significant in every equation. ${ }^{7}$

There are a number of non-significant findings that also deserve to be mentioned. First, we do not find support for the hypothesis that the presence of an environmental ministry is associated with less forest loss. The coefficients for this variable are not statistically significant in any equation of Table 2. Second, we do not find support for the idea that economic development or economic growth is related to deforestation. These variables fail to explain any significant variation in forest loss. ${ }^{8}$ Third, we do not find that nations with higher rates of total population growth are associated with higher rates of deforestation. In equations (2.1), (2.3), and (2.5), the coefficients for this variable are not statistically significant. Similarly, the coefficients for urban population growth are not statistically significant in the even numbered equations. Fourth, we do not find that it is important to account for the relative abundance or scarcity of forest resources. The coefficients for the forest stock variable are negative but not significant. ${ }^{9}$

lower rates of deforestation because these types of activities put less pressure on forests (EhrhardtMartinez, Crenshaw, and Jenkins 2002). Therefore, we examine the impact of service-based economic activity and manufacturing-based economic activity in our models. The coefficients for both of these variables fail to reach a level of statistical significance.

7 We include dummy variables for the region of the world in which a nation is located to deal with findings that may arise out of geographical circumstances, which cannot be accounted for by the independent variables in the model (Shandra 2007c). The coefficients for the geographical control variables fail to predict any significant variation in deforestation. The other findings remain similar to the results reported in Table 2 . We also seek to determine if the effects of IFC lending varies by geographical location. We test this hypothesis by including interaction terms between IFC lending and each regional dummy variable. The coefficients for the interaction terms do not reach a level of statistical significance, indicating no support for this hypothesis. This is not surprising given IFC loans are allocated fairly evenly by region, which we describe previously (International Finance Corporation 2010).

8 Ehrhardt-Martinez, Crenshaw, and Jenkins (2002) find an inverted u-shaped relationship exists between gross domestic product per capita and deforestation. We test this hypothesis using a quadratic polynomial equation in which the gross domestic product per capita and its square are entered into the same model. If this relationship exists, the sign of the coefficient for the linear term should be positive and the sign for the coefficient for the squared term should be negative and statistically significant. To reduce problems of multicollinearity, we begin by centering the linear term on its mean. We then square the centered term. Finally, we include the centered linear term and squared term in our models (York, Rosa, and Dietz, 2003). The coefficients for the squared term fail to achieve statistical significance.

9 We rerun the analysis weighting the regression estimates by forest size because the effects of IFC lending may be more pronounced in countries with larger rather than smaller forests (Rudel 1989). The findings are similar to the results of Table 2 . 


\section{DISCUSSION AND CONCLUSION}

This study expands our understanding of forest loss in a novel way. We begin by providing a review of the IFC and its operations. We go on to discuss a bit of qualitative evidence that highlights how IFC lending may increase deforestation. However, there is no cross-national research that empirically assesses this relationship. We begin to address this gap in the literature here by carrying out the first cross-national study that examines the impact of IFC lending on forest loss. We find substantial support for the idea that low and middle income nations that have received an IFC loan tend to have higher rates of deforestation than low and middle income nations that have not received a loan. We attempt to increase the reliability of the findings by demonstrating their statistical significance across several alternative model specifications and statistical techniques. ${ }^{10}$

The other findings deserve additional discussion as well. First, we find that World Bank structural adjustment and investment lending are associated with higher rates of forest loss. The coefficients for these variables are positive and significant in every equation in which they are included. This is most likely due to World Bank structural adjustment and investment loans tending to focus on boosting agricultural and forestry exports (Rich 1994). Accordingly, we find that the coefficients for the agricultural and forestry economic activity variable are positive and significant in every equation of Table 2. Further, structural adjustment lending may also be related to higher rates of forest loss because it often requires low and middle income nations to cut government spending in return for the loan (Peet 2003). This is supported by the fact that the coefficients for the environmental ministry variable fail to reach a level of statistical significance in any equation of Table 2.

Second, we find that rural population growth is associated with higher rates of forest loss. The coefficients for this variable are positive and significant in every equation in which it is included. However, other demographic measures are not associated with significant changes in forests. The coefficients for total population growth and urban population growth fail to reach a level of statistical significance in Table 2. This supports arguments by York, Rosa, and Dietz (2003) and confirmed by Jorgenson and Burns (2007) concerning the need to "decompose" demographic variables in cross-national research. The findings clearly demonstrate that it is important for researchers to examine not only overall growth rates but also population growth in different contexts, especially rural population growth, when conducting a study on deforestation.

10 As a last reliability check, we replicate the analysis using newly available satellite-based data available from DeFries et al. (2010). The results indicate that low and middle income nations that have received an IFC loan tend to have higher rates of forest loss than low and middle income nations that have not received such a loan. This analysis lends additional support to our main findings. However, we urge caution when comparing these findings to our original models. There are two factors may complicate such comparisons. First, the sample size in this supplementary analysis is much smaller than our original sample size. The satellite-derived data are available for only forty-one nations and, after listwise deletion of missing data on the independent variables, our sample is reduced to twenty-six nations. Such a small size reduces the efficiency of tests of statistical significance and calls into question the comparisons that can be made to the larger sample. Second, the satellite-derived data are only available for the period of 2000 to 2005 . We examine a more expansive period of 1990 to 2005 . 
Third, we observe some findings that contradict some initial hypotheses. In this regard, we find that higher levels of democracy are associated with higher rates of forest loss. This finding contradicts our hypothesis concerning the beneficial impact of democracy for the natural environment observed by Li and Reuveny (2006). Marquart-Pyatt (2004) finds the same result in her cross-national study of forest loss. She suggests that it is the due to the influence of money from business in politics of low and middle income nations as well as government leaders in these nations having to meet competing interests (e.g., business versus environment). We also observe that higher levels of debt service correspond with lower rates of deforestation, which contradicts Shandra, Shandra, and London's (2008) findings. Nevertheless, Capistrano (1994) finds that debt service has a similar effect on forest loss in her cross-national study. She attributes this finding to higher fossil fuel prices, which not only prompts countries to borrow money to maintain an adequate supply of imports but also raises the cost of running logging and agricultural operations, reducing expansion of such activities and, in turn, forest loss.

There are some theoretical implications that correspond with the main findings of our study. We note in the introduction that cross-national research on the natural environment informed by dependency theory tends to focus on the impact of World Bank structural adjustment loans (e.g., Shandra, Shircliff, and London 2010). There is also an extensive cross-national literature that finds foreign investment has a harmful impact on the environment (e.g., Jorgenson 2008). Nevertheless, dependency theory has very little to say about the impact of loans directly to foreign investors by multilateral institutions on the environment--see Karliner (1997) as a notable exception. We attempt to fill in this gap in dependency theory by showing how the IFC works and demonstrating that its lending in extractive sectors is associated with increased forest loss.

We should also comment on the methodological implications of the study. The results correspond with ideas put forth by Jorgenson (2008), who "decomposes" foreign investment into different sectors (i.e., primary, secondary, and tertiary sectors) and examines their impact on forest loss. In doing so, the author finds that higher levels of primary sector foreign investment (e.g., logging, agriculture, mining, etc.) are associated with higher rates of deforestation. We extend this line of reasoning here but in two different ways. First, we decompose World Bank lending by sector and demonstrate that low and middle income nations that receive a World Bank IFC loan in the primary sector tend to have higher rates of forest loss than low and middle income nations that have not received such a loan. We also find that structural adjustment and investment loans in the agriculture, forestry, and mining sectors are associated with higher rates of deforestation. Second, we decompose World Bank lending by type and examine how IFC loans, structural adjustment loans, and investment loans affect the natural environment. Thus, we contend that it is necessary to move beyond examining just the impact of whether or not a nation has received a loan from the World Bank. Rather, cross-national researchers should use newly available data on the specific sectors in which a loan has been given. Further, they should also consider how different types of World Bank lending affect forests. In doing so, scholars can conduct more nuanced and accurate empirical evaluations of how the World Bank influences the natural environment. This will also allow for more accurate policy suggestions to deal with the causes of forest loss.

Accordingly, it may serve non-governmental organizations, social movements, and concerned citizens well to monitor and publicize the environmental impacts of the IFC's lending to corporations (Park 2005). Further, non-governmental organizations, social movements, and 
environmentalists should lobby the World Bank leaders to change their lending policies to include better environmental safeguards. However, these groups may be best served by focusing their attention on the lawmakers in the nations that fund the World Bank (Goldman 2005).

This was the approach taken by the National Wildlife Federation and Environmental Policy Institute against the World Bank to stop the financing of a resettlement project generating massive forest loss in the Brazilian Amazon during the 1980s (Rich 1994). While protests directed by the non-governmental organizations at the World Bank achieved little, a well publicized media campaign in the United States Congress forced the World Bank to stop remaining loan disbursements "pending the preparation and carrying out of emergency environmental and Indian lands protection measures by the Brazilian government" (Rich 1994: 126). This media campaign involved working with non-governmental organizations in Brazil to document how forest loss was affecting local people and then publicizing the findings in the media (Bryant and Bailey 1997). These non-governmental organizations also brought people affected by the deforestation to tell their stories before the Unites States Congress (Barbosa 2001). Such an approach may prove to be effective in bringing about changes at the IFC (Park 2005).

We conclude with some possible directions for future research. First, we note above that the World Bank's Multilateral Guarantee Agency often provides insurance to foreign investors that participate in IFC loans (Karliner 1997). However, there has been no cross-national research to our knowledge that examines how the Multilateral Guarantee Agency's operations affect the natural environment. Second, we use cross-national data over a span of fifteen years (i.e., 19902005) to examine how the IFC affects forests. Unfortunately, comparable data on deforestation are limited to this time period due to changes in collection methodologies (Food and Agriculture Organization 2005). However, it may well be that macro-structural changes occur over longer periods of time. When longitudinal data become available panel regression techniques should be used to analyze forest loss. Further, cross-national research should be supplemented with fieldwork or case study analysis.

\section{REFERENCES}

Abouharb, M. Rodwan and David Cingranelli. 2009. "International Monetary Programs and Human Rights, 1981-2003." The Review of International Organizations 4: 47-72.

Amin, Samin. 1976. Unequal Development: An Essay on the Social Formation of Peripheral Capitalism. New York, Monthly Review Press.

Austin, Kelly. 2010. "Soybean Exports and Deforestation in a World Systems Perspective: A Cross-National Analysis of Comparative Disadvantage." Sociological Quarterly 51: 511536.

Barbosa, Luis C. 2001. The Brazilian Amazon Rainforest: Global Ecopolitics, Development, and Democracy. New York: University of America Press.

Bornschier Volker and Christopher. Chase-Dunn. 1985. Transnational Corporations and Underdevelopment. Praeger: New York.

Bryant, Raymond L. and Sinead Bailey. 1997. Third World Political Ecology. London: Routledge. 
Bowles, Ian A., Amy B. Rosenfeld, Cyril F. Kormos, James D. Nations, and Thomas T. Ankerton. (1999). "The Environmental Impacts of International Finance Corporation Lending and Proposals for Reform: A Case Study of Conservation and Oil Development in the Guatemalan Peten." Environmental Law 29: 57-79.

Burns, Thomas J., Eedward L. Kick, and Byron L. Davis. 2003. "Theorizing and Rethinking Linkages between the Natural Environment and the Modern World System: Deforestation in the Late $20^{\text {th }}$ Century." Journal of World-Systems Research 9: 357-390.

Capistrano, Ann D. 1994. "Tropical Forest Depletion and the Changing Macroeconomy, 196785." in The Causes of Tropical Deforestation, edited by Katrina Brown and David Pearce. University of California Press.

Clapp, Jennifer and Peter Dauvergne. 2005. Paths to a Green World: The Political Economy of the Global Environment. Cambridge: MIT Press.

DeFries, Ruth S., Thomas, K. Rudel, Maria Uriarte, and Matthew Hansen. 2010. "Deforestation Drive by Urban Population Growth and Agricultural Trade in the Twenty-First Century." Nature Geoscience 3: 178-181.

Ehrhardt-Martinez, Karen, Edward M. Crenshaw, and J. Craig Jenkins. 2002. "Deforestation and the Environmental Kuznets Curve: A Cross-National Investigation of Intervening Mechanisms." Social Science Quarterly 83: 226-43.

Ehrhardt-Martinez, Karen. 1998. "Social Determinants of Deforestation in Developing Countries." Social Forces 77: 567-86.

Evans, Peter B. 1979. Dependent Development: The Alliance of Multinational, State, and Local Capital in Brazil. Princeton: Princeton University Press.

Fearnside, Pau M. 2007. "Brazil's Cuiaba-Santarem highwway: The Environmental Cost of Paving a Soybean Corridor in the Amazon." Environmental Management 39: 601-614.

Findley, M. G., D. Hawkins, R. L. Hicks, D. L. Nielson, B. C. Parks, R. M. Powers, J. T. Roberts, M. J. Tierney, and S. Wilson. 2010. "AidData: Tracking Development Finance." Conference Paper Presented at Aid Transparency and Development Finance: Lessons and Insights from AidData. Oxford: United Kingdom.

Food and Agriculture Organization of the United Nations. 2005. Global Forest resources Assessment 2005: Progress Towards Sustainable Forest Management. Rome: United Nations.

Forest Peoples Programe. 2007. Procedural Irregularities and Standard Violations in International Finance Corporation Support for Wilmar Trading. Merton-In-Marsh: Forest Peoples Program.

Frank, Andre Gunder 1967. Capitalism and Underdevelopment in Latin America. New York: Monthly Review Press.

Frank, David J., Ann Hironaka, and Evan Schofer. 2000. "The Nation-State and the Natural Environment over the Twentieth century." American Sociological Review 65: 96-116.

Frank, David J. 1999. "The Social Bases of Environmental Treaty Ratification." Sociological Inquiry 69: 523-550.

Freedom House. 1997. Freedom in the World. New York: Freedom House.

Friedman, Lisa 2009. "How the World Bank Let Deal Making Torch the Rainforests." New York Times.

George, Susan, and Fabrizio Sabelli. 1994. Faith and Credit: The World Bank's Secular Empire. Boulder: Westview Press. 
George, Susan. 1992. The Debt Bomerang. Boulder: Westview Press.

Glover, David. 1995. "Structural Adjustment and the Environment." Journal of International Development 7: 285-289.

Goldman, Michael. 2005. Imperial Nature: The World Bank and Struggles for Social Justice in the Era of Globalization. New Haven: Yale University Press.

Greene, William H. 2000. Econometric Analysis. Upper Saddle River: Prentice-Hall.

Hurst, Philip. 1990. Rainforest Politics. London: Zed Books.

International Finance Corporation. 2010. IFC's Annual Report 2010. Washington: World Bank . 2009. IFC's Annual Report 2009. Washington: World Bank. 2008. IFC's Annual Report 2008. Washington: World Bank. 2007. IFC's Annual Report 2007. Washington: World Bank. 2005. IFC's Annual Report 2005. Washington: World Bank.

Jorgenson, Andrew K., Kelly Austin, and Christopher Dick. 2009. "Ecologically Unequal Exchange and the Resource/Consumption and Environmental Degradation Paradox." International Journal of Comparative Sociology 50: 263-284.

Jorgenson, Andrew K.., and Thomas J. Burns. 2007. "Effects of Rural and Urban Population and National Development on Deforestation in Less Developed Countries, 1990-2000." Sociological Inquiry 77: 460-482.

Jorgenson, Andrew K. 2008. "Structural Integration and the Trees: An Analysis of Deforestation in Less-Developed Countries, 1990-2005." Sociological Quarterly 49: 503-527. . 2006. "Unequal Exchange and Environmental Degradation: A Theoretical Proposition and Cross-National Study of Deforestation." Rural Sociology 71: 108-125.

Karliner, Joshua 1997. The Corporate Planet. San Francisco: Sierra Club.

Li, Quan and Rafael Reuveny. 2006. "Democracy and environmental degradation." International Studies Quarterly 50: 935-956.

Lilley, Sasha. 2004. "Paving the Amazon with Soy." Corporate Watch: San Francisco.

McMichael, Philip. 2004. Development and Social Change: A Global Perspective. Thousand Oaks: Pine Forge Press.

Maddala, G. S. 1986. Limited Dependent and Qualitative Variables in Econometrics. New York: Cambridge University Press.

Magdoff, Harry. 1986. Third World debt: Past and present. Monthly Review 38, 1-10.

Marquart-Pyatt, Sandra. 2004. "A Cross-National Analysis of Deforestation, Debt, State Fiscal Capacity, and the Environmental Kuznets Curve." International Journal of Sociology 34: 33-51.

Midlarsky, Manus I. 1998. Democracy and the environment: An empirical assessment. Journal of Peace Research 35:341-361.

Olsen, Randall J. 1980. "A Least Squares Correction for Selectivity Bias." Econometrica 48: $1815-1820$.

Park, Susan K. 2005. "How Transnational Environmental Advocacy Networks Socialize International Financial Institutions: A Case Study of the International Finance Corporation." Global Environmental Politics 5: 95-119.

Paxton, Pamela. 2002. "Social Capital and Democracy: An Interdependent Relationship." American Sociological Review 67: 254-77.

Peet, Richard. 2003. The Unholy Trinity: The International Monetary Fund, World Bank, and World Trade Organization. London: Zed Books. 
Puhani, Patrick A. 2000. "The Heckman Correction for Sample Selection and Its Critique." Journal of Economic Surveys 14: 53-68.

Rich, Bruce A. 1994. Mortgaging the Earth: The World Bank, Environmental Impoverishment, and the Crisis of Development. Boston: Beacon Press.

River, Jorge, Peter de Leon, and Charles Koerber. 2006. "Is Greener Whiter Yet? The Sustainable Slopes Program After Five Years.” Policy Studies Journal 34: 195-226.

Rudel, Thomas and Jill Roper. 1997. The paths to rain forest destruction: Cross-national patterns of tropical deforestation, 1975-1990. World Development 25, 53-65.

Rudel, Thomas. 1993. Tropical Deforestation: Small Farmers and Land Clearing in the Ecuadorian Amazon. New York: Columbia University Press.

1989. "Population, Development, and Tropical Deforestation: A Cross-National Study." Rural Sociology 54: 327-38.

Schofer, Evan and Ann Hironaka. 2005. "The Effects of World Society on Environmental Outcomes." Social Forces 84: 25-47.

Shandra, John M., Eric Shircliff, and Bruce London. 2010. "The International Monetary Fund, World Bank, and Structural Adjustment: A Cross-National Analysis of Forest Loss." Social Science Research 40: 210-245.

Shandra, John M., Christopher Leckband, and Bruce London. 2009. "Ecologically Unequal Exchange and Deforestation: A Cross-National Analysis." Organization \& Environment 22: 293-310.

Shandra, John M., Carrie L. Shandra, and Bruce London. 2008. "Women, Non-governmental Organizations, and Deforestation: A Cross-National Study." Population and Environment 38: 48-72.

Shandra, John M. 2007a. "The World Polity and Deforestation: A Cross-National Analysis." International Journal of Comparative Sociology 48: 5-28.

2007b. "Non-Governmental Organizations and Deforestation: Good, Bad, or Irrelevant." Social Science Quarterly 88: 665-689.

2007c. "Economic Dependency, Repression, and Deforestation: A Cross-National Analysis." Sociological Inquiry 77: 543-571.

Smith, Jackie and Dawn Wiest. 2005. "The Uneven Geography of Global Civil Society: National and Global Influences on Transnational Associations." Social Forces 84: 632652.

Tockman, Jason. 2001. The International Monetary Fund: Funding Deforestation. Washington: American Lands Alliance.

World Bank. 2010. World Bank Project and Operations Database. Washington: World Bank. 2003. World Development Indicators. Washington: World Bank.

World Rainforest Movement. 2005. Open for Business: How the International Finance Corporation Subsidies the Pulp and Paper Industry. Montevideo: Uruguay.

World Rainforest Movement. 2004. International Finance Corporation Backs Australian Gold Mine in Laos. Montevideo: Uruguay.

World Resources Institute. 2005. World Resources 2005: The Wealth of the Poor. Washington: World Resources Institute.

York, Richard, Eugene A. Rosa, and Thomas Dietz. 2003. "Footprints on the Earth: The Environmental Consequences of Modernity." American Sociological Review 68: 279300 . 